\title{
NMDA Receptor Signaling Is Important for Neural Tube Formation and for Preventing Antiepileptic Drug-Induced Neural Tube Defects
}

\author{
๑Eduardo B. Sequerra, ${ }^{*}$ Raman Goyal, ${ }^{\circledR}$ Patricio A. Castro, Jacqueline B. Levin, and $\complement^{\circ}$ Laura N. Borodinsky \\ Department of Physiology and Membrane Biology and Institute for Pediatric Regenerative Medicine, Shriners Hospital for Children, University of California \\ Davis School of Medicine, Sacramento, California 95817
}

Failure of neural tube closure leads to neural tube defects (NTDs), which can have serious neurological consequences or be lethal. Use of antiepileptic drugs (AEDs) during pregnancy increases the incidence of NTDs in offspring by unknown mechanisms. Here we show that during Xenopus laevis neural tube formation, neural plate cells exhibit spontaneous calcium dynamics that are partially mediated by glutamate signaling. We demonstrate that NMDA receptors are important for the formation of the neural tube and that the loss of their function induces an increase in neural plate cell proliferation and impairs neural cell migration, which result in NTDs. We present evidence that the AED valproic acid perturbs glutamate signaling, leading to NTDs that are rescued with varied efficacy by preventing DNA synthesis, activating NMDA receptors, or recruiting the NMDA receptor target ERK1/2. These findings may prompt mechanistic identification of AEDs that do not interfere with neural tube formation.

Key words: birth defects; calcium dynamics; epilepsy; glutamate signaling; neural plate; valproic acid

\section{Significance Statement}

Neural tube defects are one of the most common birth defects. Clinical investigations have determined that the use of antiepileptic drugs during pregnancy increases the incidence of these defects in the offspring by unknown mechanisms. This study discovers that glutamate signaling regulates neural plate cell proliferation and oriented migration and is necessary for neural tube formation. We demonstrate that the widely used antiepileptic drug valproic acid interferes with glutamate signaling and consequently induces neural tube defects, challenging the current hypotheses arguing that they are side effects of this antiepileptic drug that cause the increased incidence of these defects. Understanding the mechanisms of neurotransmitter signaling during neural tube formation may contribute to the identification and development of antiepileptic drugs that are safer during pregnancy.

\section{Introduction}

Development of the vertebrate nervous system starts with the induction of ectodermal cells to become neural cells. They constitute the neural plate that subsequently folds to form the neural tube. Neural tube defects (NTDs) are malformations associated with the failure of the neural tube to close (Wallingford et al., 2013). This

\footnotetext{
Received Sept. 13, 2017; revised April 3, 2018; accepted April 12, 2018.

Author contributions: E.B.S., R.G., P.A.C., J.B.L., and L.N.B. designed research; E.B.S., R.G., P.A.C., and J.B.L. performed research; E.B.S., R.G., P.A.C., J.B.L., and L.N.B. analyzed data; E.B.S., R.G., P.A.C., J.B.L., and L.N.B. wrote the paper.

This work was supported by the Basil O'Connor Starter Scholar Research Award Grant 5-FY09-131 from the March of Dimes Foundation; a Klingenstein Foundation Award in Neuroscience; National Science Foundation Grant 1120796; National Institutes of Health-National Institute of Neurological Disorders and Stroke Grant R01-NS073055; and Shriners Hospital for Children Grants 86500-NCA, 85220-NCA, and 85300-NCA (to L.N.B.); and by the Epilepsy Foundation and Shriners Hospital for Children postdoctoral fellowships (to E.B.S.). We thank Drs. Nicholas Spitzer and Andrew Hamilton for comments on the manuscript.

*E.B.S. and R.G. contributed equally to this work.

The authors declare no competing financial interests.
}

leads to in utero degeneration of exposed neural tissue and, depending on the location and severity of the defect, can cause perinatal lethality or severe neurological deficit in surviving individuals. NTDs are among the most common serious morphological defects diagnosed in human fetuses and newborns, with a combined incidence of $\sim 1$ in 1000. Environmental and genetic factors both contribute to the incidence of NTDs (Wallingford et al., 2013).

Offspring of epileptic mothers exhibit an increased incidence in NTDs associated with the use of antiepileptic drugs (AEDs)

Correspondence should be addressed to Laura N. Borodinsky, Department of Physiology and Membrane Biology, and Institute for Pediatric Regenerative Medicine, Shriners Hospital for Children, University of California Davis School of Medicine, Sacramento, CA 95817. E-mail: Inborodinsky@ucdavis.edu.

E. B. Sequerra's present address: Brain Institute, Universidade Federal do Rio Grande do Norte, 59056-450, Natal, RN, Brazil.

P. A. Castro's present address: Department of Physiology, Universidad de Concepcion, Concepcion, Chile 4030000.

DOI:10.1523/JNEUROSCI.2634-17.2018

Copyright $\odot 2018$ the authors $\quad 0270-6474 / 18 / 384762-12 \$ 15.00 / 0$ 
during pregnancy (Robert and Guibaud, 1982; Lindhout and Schmidt, 1986; Rosa, 1991). Valproic acid (VPA) and carbamazepine, widely used AEDs, have been shown to increase the incidence of NTDs both in epidemiological and animal studies (Rosa, 1991; Lindhout et al., 1992; Padmanabhan and Ahmed, 1996). However, the mechanisms underlying AED-induced NTDs remain unclear. Most hypotheses have centered on AED side effects (Wegner and Nau, 1992; Finnell et al., 2003; Gurvich et al., 2005) and not on AED primary targets. Nevertheless, a direct causeeffect relationship between AED side effects and NTDs is still lacking. AEDs prevent seizures in the mature brain by targeting ion channels, neurotransmitter transporters, neurotransmitter metabolic enzymes, or neurotransmitter receptors (Rogawski and Löscher, 2004). Whether there is neurotransmitter signaling in the developing neural tube and AEDs affect it remain uncertain.

Electrical activity and neurotransmitter signaling have been shown to regulate nervous system development even before synapses are formed (Spitzer, 2006). Long after neurulation occurs, neurotransmitter signaling affects neural progenitor proliferation in the developing and adult rodent nervous system (Gould et al., 1994; LoTurco et al., 1995; Luk et al., 2003; Young et al., 2011) and regulates the migration of telencephalic progenitors (Manent et al., 2005, 2006; Bortone and Polleux, 2009), both of which are cellular processes that are required for neural tube formation. The role of neurotransmitter signaling in neural tube formation has not been previously investigated; however, it has been shown that neurotransmitters and neurotransmitter receptors are already expressed at early stages of development including neural plate stages (Lauder et al., 1981; Kapur et al., 1991; Rowe et al., 1993; Root et al., 2008).

Here, we demonstrate the role of glutamate signaling during neurulation and the relevance to the cellular and molecular mechanisms underlying VPA-mediated NTDs in Xenopus laevis embryos. We find that neural plate cells exhibit $\mathrm{Ca}^{2+}$ transients that are in part mediated by glutamate through NMDA receptors (NMDARs). This signaling regulates neural plate cell proliferation and migration, and perturbation of this signaling by VPA disrupts neural plate folding and neural tube formation leading to NTDs.

\section{Materials and Methods}

Animals. Embryos were generated by in vitro fertilization. Mature oocytes were collected in a dish from a previously human chorionic gonadotropin-injected female frog and exposed to a small piece of minced testis. This is considered time 0 of fertilization. Fertilized oocytes were kept in a $10 \%$ Marc's Modified Ringer's (MMR) saline solution containing the following (in $\mathrm{mm}$ ): $10 \mathrm{NaCl}, 0.2 \mathrm{KCl}, 0.1 \mathrm{MgSO}_{4}, 0.5$ HEPES, $5 \mathrm{EDTA}$, and $0.2 \mathrm{CaCl}_{2}$. Dejellying of embryos was performed by briefly swirling fertilized eggs in $2 \%$ cysteine solution in $10 \% \mathrm{MMR}, \mathrm{pH}$ 8. Animals were handled according to the Institutional Animal Care and Use Committee guidelines and under an approved animal protocol using humane procedures.

$\mathrm{Ca}^{2+}$ imaging in vivo. DNA encoding the $\mathrm{Ca}^{2+}$ sensor GCaMP6s (pGP-CMV-GCaMP6s, a gift from Douglas Kim, ((HHMI Janelia Research Campus, Ashburn, Virginia); plasmid \#40753, Addgene; Chen et al., 2013) was subcloned into the pCS2 ${ }^{+}$vector using BglII and NotI restriction sites. The BglII restriction site was included in pCS2 with the following primers: forward, 5'-TCACTAAAGGGAACAAAAGATCTG GGTACCGGGCCCAA-3'; reverse, 5' -TTGGGCCCGGTACCCAGATC TTTTGTTCCCTTTAGTGA-3'. For all experiments in this study, mRNA was transcribed from the indicated plasmids using mMessage mMachine kits (Ambion). GCaMP6s mRNA was injected in two-cellstage embryos (1 ng mRNA/embryo). Neural plate stage embryos [14-19 h postfertilization (hpf)] were imaged under a macroscope (model
AZ100, Nikon) at an acquisition rate of $0.1 \mathrm{~Hz}$ for $2 \mathrm{~h}$. Detection of $\mathrm{Ca}^{2+}$ transients was thresholded by a peak change in fluorescence of at least 2 times the noise, as in previous studies (Borodinsky et al., 2004; Borodinsky and Spitzer, 2007; Belgacem and Borodinsky, 2011; Swapna and Borodinsky, 2012; Tu and Borodinsky, 2014). The number of $\mathrm{Ca}^{2+}$ transients at different developmental stages in the presence or absence of drugs, in $\mathrm{Ca}^{2+}$-free saline, or in unilaterally injected GluN1-Mo embryos were compared, and significance was assessed by paired $t$ test or one-way ANOVA followed by Tukey's or Dunnett's post hoc tests.

$\mathrm{Ca}^{2+}$ imaging in vitro. Neural plate cells from stage 15 embryos were dissociated and plated in a culture dish as previously described (Borodinsky et al., 2004; Borodinsky and Spitzer, 2007; Belgacem and Borodinsky, 2011; Swapna and Borodinsky, 2012). Cells were allowed to attach to the dish for $30 \mathrm{~min}$ followed by incubation with $1 \mu \mathrm{M} \mathrm{Ca}{ }^{2+}$-sensitive dye Fluo4-AM (Thermo Fisher Scientific) for $45 \mathrm{~min}$. After washing off the excess of Fluo4-AM, cells were time-lapse imaged under a Swept-field confocal microscope (Nikon) with an acquisition rate of $0.2 \mathrm{~Hz}$ during addition of $5 \mathrm{~mm}$ glutamate or $10 \mu \mathrm{M}$ NMDA for 5 min to record the $\mathrm{Ca}^{2+}$ response to these agents in control conditions. Cells were then washed and incubated with $100 \mu \mathrm{M}$ VPA for 30 min followed by the addition of glutamate or NMDA to record the $\mathrm{Ca}^{2+}$ response to these agents in the same cells in the presence of VPA. Cell cultures were washed, and the response to glutamate and NMDA was recorded for a third time in the same cells. The number of responsive cells of the total number of cells in the field of view was determined in each recording period, and differences were assessed by paired comparisons in each experiment.

$R T$-PCR. Total mRNA was isolated from dorsal-half neural plate-stage embryos ( $15 \mathrm{hpf}$ ) using the RNeasy Kit (Qiagen). cDNA was synthesized from $2 \mu \mathrm{g}$ of mRNA using the Reverse Transcription Kit (Qiagen) according to manufacturer instructions. The following specific primers were used: GluN1: forward, 5' -GGCTGTGCTGGAGTTTGAGG-3'; reverse. 5'-ATCCTTGTGCCGCTTGTAGG-3'; GluA1: forward, 5'-GG CAGATTGTGATCGACTGC-3' ${ }^{\prime}$; reverse, $5^{\prime}$-CCACTGCTGCATGATT CTGG-3'; vesicular glutamate transporter 1 (VGluT1): forward, 5' GCAACTTGGGTGTAGCCATT-3'; reverse, 5'-TGCCCATTTACTCC AGATCC-3'; excitatory amino acid transporter 5 (EAAT5): forward, 5'-GTGGGATGTCTGCTTGGATT-3'; reverse, 5'-ATGTGGCTTCCA CAAGGTTC-3'; syntaxin 1a (Stx1A): forward, 5'-ATGAAGGATCG GACCAGGGA-3'; reverse, 5'-TGTGGCGTTGTATTCGGACA-3'; vesicle-associated membrane protein 1 (VAMP1): forward, 5'-GCCA CAGGTGATCCTGGAAA-3'; reverse, 5'-AGGAGACGCTCCACAC AATG-3'; synaptosomal-associated protein 25 (SNAP25): forward, 5' AAGGCTTGGGGCAATAACCA-3'; reverse, 5'-AACCACTGCCCAGC ATCTTT-3', designed using Primer-BLAST (www.ncbi.nlm.nih.gov).

Western blot assays. Whole embryos were homogenized in extraction buffer containing $1 \%$ Triton X-100, $150 \mathrm{~mm} \mathrm{NaCl}, 25 \mathrm{~mm}$ Tris pH 7.4, 1 mM EDTA, 1 mm EGTA, and protease inhibitors cocktail (Thermo Fisher Scientific). Samples were centrifuged at 16,100 rpm for $10 \mathrm{~min}$, and the pellet was discarded. Supernatant was then boiled with Laemmli buffer and run on a $10 \%$ SDS-PAGE gels followed by protein transfer to PVDF membrane and incubation with GluN1 1:500 (catalog \#AB9864, EMD Millipore) and GAPDH 1:20,000 (catalog \#sc-47724 Santa Cruz Biotechnology, as a protein loading control) antibodies.

For pERK1/2 Western blot assays, stage 15 embryos were snap frozen, then homogenized in RIPA buffer containing $50 \mathrm{~mm}$ Tris, $\mathrm{pH} 7.5,150$ $\mathrm{mm} \mathrm{NaCl}, 0.5 \%$ NP-40, 0.05\% SDS, $0.002 \%$ EDTA, protease inhibitor cocktail, and phosphatase inhibitor cocktail (Sigma-Aldrich). Samples were then processed as described above. Membranes with transferred proteins were probed with antibodies for pERK1/2 1:300 (catalog \#4377S, Cell Signaling Technology), ERK1/2 1:500 (catalog \#4377S, Cell Signaling Technology), ER $\alpha$ 1:1000 (catalog \#sc-542, Santa Cruz Biotechnology), and $\alpha$-tubulin 1:500 (catalog \#T9026, Sigma-Aldrich), then they were probed with fluorescent secondary antibodies 1:10,000 (LICOR) using SNAP id 2.0 (EMD Millipore) and imaged on Odyssey CLx (LI-COR).

Immunohistochemistry. Stage 13-24 embryos were fixed for $2 \mathrm{~h}$ or 25 min at $4^{\circ} \mathrm{C}$ or $23^{\circ} \mathrm{C}$, respectively, with freshly made $4 \%$ paraformaldehyde (PFA) or for $1 \mathrm{~h}$ at $23^{\circ} \mathrm{C}$ with $2 \%$ trichloroacetic acid, which better 


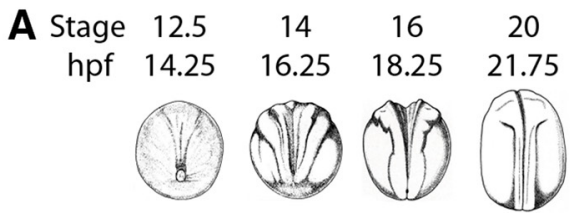

B Superficial neural plate cell - Stage 14

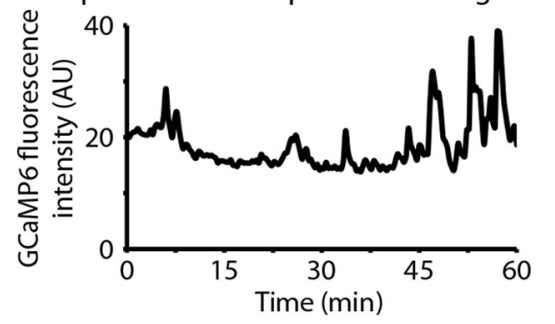

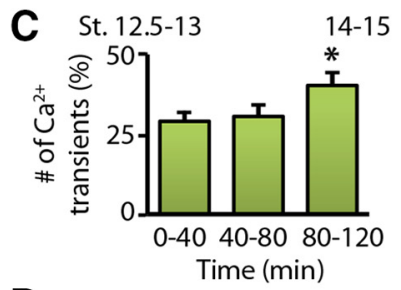

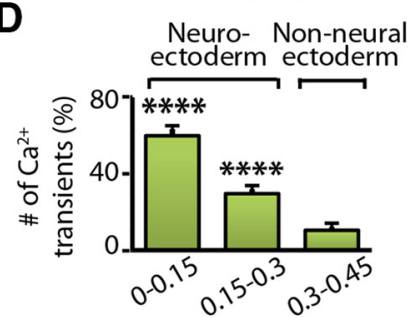

Distance from midline $(\mathrm{mm})$
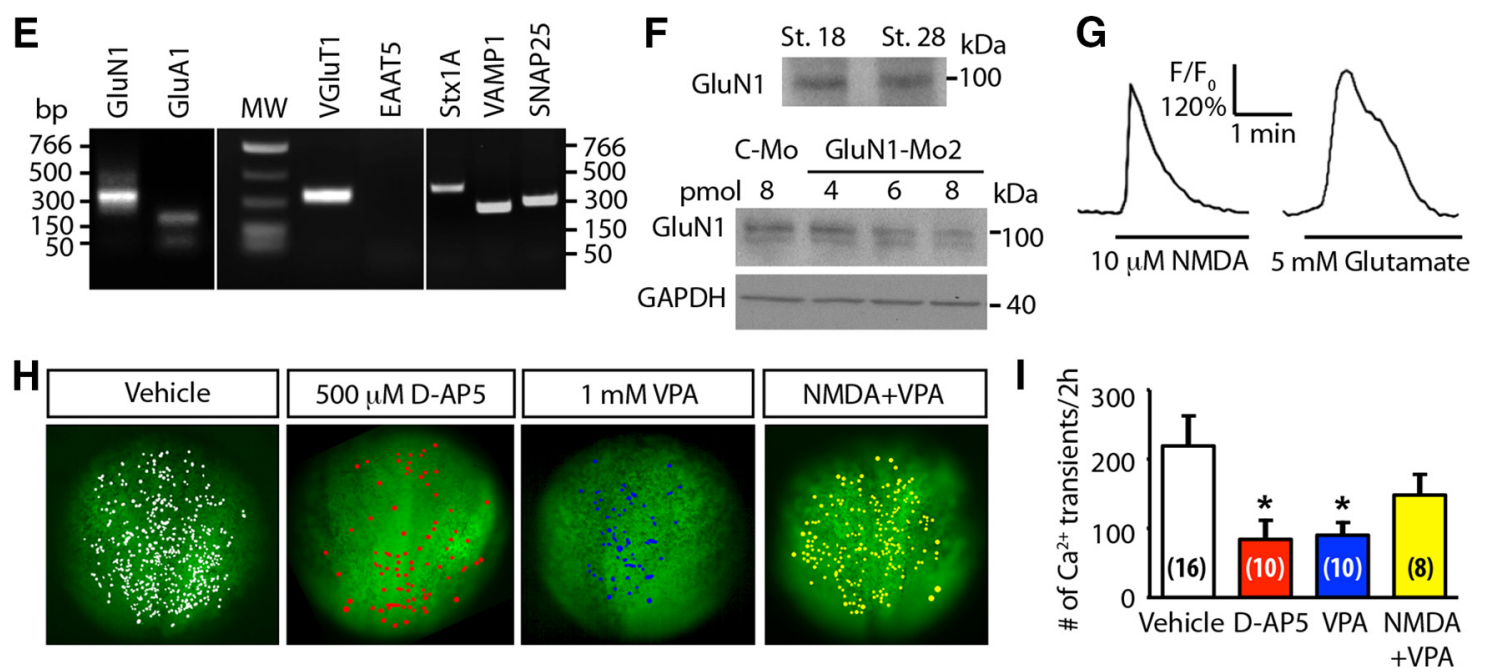

Figure 1. $\quad \mathrm{Ca}^{2+}$ dynamics and glutamate signaling are present during neural tube formation. $A$, Developmental stages of $X$. laevis neural tube formation. hpf: hours post fertilization, hpf at $23^{\circ} \mathrm{C}$. Adapted from the study by Nieuwkoop and Faber (1994). $\boldsymbol{B}$, Representative trace of in vivo spontaneous changes in the $\mathrm{Ca}^{2+}$ sensor GCaMP6s fluorescence in a neural plate cell from a neurulating stage 14 embryo. C, Frequency of $\mathrm{Ca}^{2+}$ transients (per 40 min period, percentage of total number of transients in $2 \mathrm{~h}$ period, stages $12.5-14$ ); values are the mean \pm SEM, $n=12$ embryos, ${ }^{*} p<$ 0.05 , ANOVA followed by Dunnett's test, compared with first 40 min period. St., Stage. $\boldsymbol{D}$, Distribution of $\mathrm{Ca}^{2+}$ transients (per $2 \mathrm{~h}$ period) in the dorsal ectoderm (percentage of the total number of transients per $2 \mathrm{~h}$ period, stages $12.5-14$ ); values are the mean \pm SEM,$n=15$ embryos. ${ }^{* * * *} p<0.0001$, ANOVA followed by Dunnett's test compared with the most lateral region. $\boldsymbol{E}$, RT-PCR from the dorsal half of stage 13 embryos. $F$, Western blot assay from whole-embryo lysates at neural plate (stage 18) and tailbud (stage 28) stages (top), and from neural plate stage (stage 18) embryos injected at the two-cell stage with C-Mo or GluN1-Mo2 (bottom). Similar results were obtained in three independent experiments. G, Traces from stage 15-dissociated neural plate cells loaded with the $\mathrm{Ca}^{2+}$-sensitive dye Flu04-AM and imaged during the addition of $10 \mu \mathrm{M} \mathrm{NMDA}$ or $5 \mathrm{~mm}$ glutamate. Lines under the traces indicate the time of incubation with NMDA or glutamate. Samples were time-lapse imaged at a rate of $0.2 \mathrm{~Hz}$ for $5 \mathrm{~min}$. Regions of interest were selected to measure the fluorescence intensity over time for individual neural plate cells with NIS Elements software (Nikon). Fluorescence $(\mathrm{F})$ is normalized to the baseline for each cell $\left(\mathrm{F}_{0}\right)$ as a percentage. $\boldsymbol{H}$, Examples of $\mathrm{GCaMP6s-expressing} \mathrm{embryos} \mathrm{imaged} \mathrm{in} \mathrm{the} \mathrm{absence} \mathrm{(vehicle)} \mathrm{or} \mathrm{presence} \mathrm{of} \mathrm{the} \mathrm{indicated} \mathrm{drugs} \mathrm{for}$ $2 \mathrm{~h}$ starting at stage 12.5. Circles indicate the occurrence of $\mathrm{Ca}^{2+}$ transients. Ten micromolar NMDA was preincubated for 30 min before the addition of $1 \mathrm{~mm}$ VPA (NMDA + VPA). $I$, Frequency of $\mathrm{Ca}^{2+}$ transients (per $2 \mathrm{~h}$ period, stages $12.5-14$ ); values are the mean \pm SEM, numbers between parentheses are the number of embryos per treatment. ${ }^{*} p<0.05$, one-way ANOVA, followed by Dunnett's test compared with vehicle-treated samples.

preserves membrane proteins and neural plate cell subcellular structures, and were processed for tissue sectioning (10-30 $\mu \mathrm{m}$ thick) and immunostaining as previously described (Swapna and Borodinsky, 2012; Belgacem and Borodinsky, 2015; Balashova et al., 2017). Incubations with primary and secondary antibodies were performed overnight at $4^{\circ} \mathrm{C}$ and for $2 \mathrm{~h}$ at $23^{\circ} \mathrm{C}$, respectively. The following primary antibodies were used: anti-E-cadherin 5D3 1:10 (Developmental Studies Hybridoma Bank at the University of Iowa, Iowa City, IA) to label the non-neural ectoderm; anti-Sox2 1:100 (catalog \#AF2018, R\&D Systems) to label the neural ectoderm; anti-PCNA (proliferating cell nuclear antigen) 1:500 (catalog \#AV03018, Sigma-Aldrich) to label proliferating cells; anti-PH3 (phospho-histone 3) 1:100 (catalog \#06-570, EMD Millipore) to label mitotic cells; and anti-BrdU (bromodeoxyuridine) 1:500 (catalog \#MCA2483, Bio-Rad) to label proliferating cells that have gone through $S$ phase. Tissue sections for BrdU immunostaining were microwaved in
$10 \mathrm{~mm}$ sodium citrate, $\mathrm{pH}$ 6.0. For all other antigens, retrieval was performed by microwaving samples in $0.05 \%$ citraconic anhydride, $\mathrm{pH} 7.4$ (Namimatsu et al., 2005).

Counterstaining of transverse embryo sections was performed with phalloidin-Alexa Fluor 488 conjugate (Thermo Fisher Scientific) to stain F-actin according to the manufacturer protocol.

Whole-mount immunostaining was performed by fixing stage 13 through 18 embryos with $4 \%$ PFA for $2 \mathrm{~h}$ at $23^{\circ} \mathrm{C}$ or overnight at $4^{\circ} \mathrm{C}$ followed by transection to isolate the dorsal half containing the neural plate. Samples were dehydrated with methanol and bleached using $\mathrm{H}_{2} \mathrm{O}_{2}$ in Dent's fixative ( $80 \%$ methanol/20\% dimethylsulfoxide), then rehydrated before blocking and staining. Primary and secondary antibody incubations were performed overnight at $4^{\circ} \mathrm{C}$ and for $2 \mathrm{~h}$ at $23^{\circ} \mathrm{C}$, respectively. The antibodies used were pERK1/2 1:200 (catalog \#4377S, Cell Signaling Technology), Sox2 1:200 (catalog \#AF2018, R\&D Systems), 


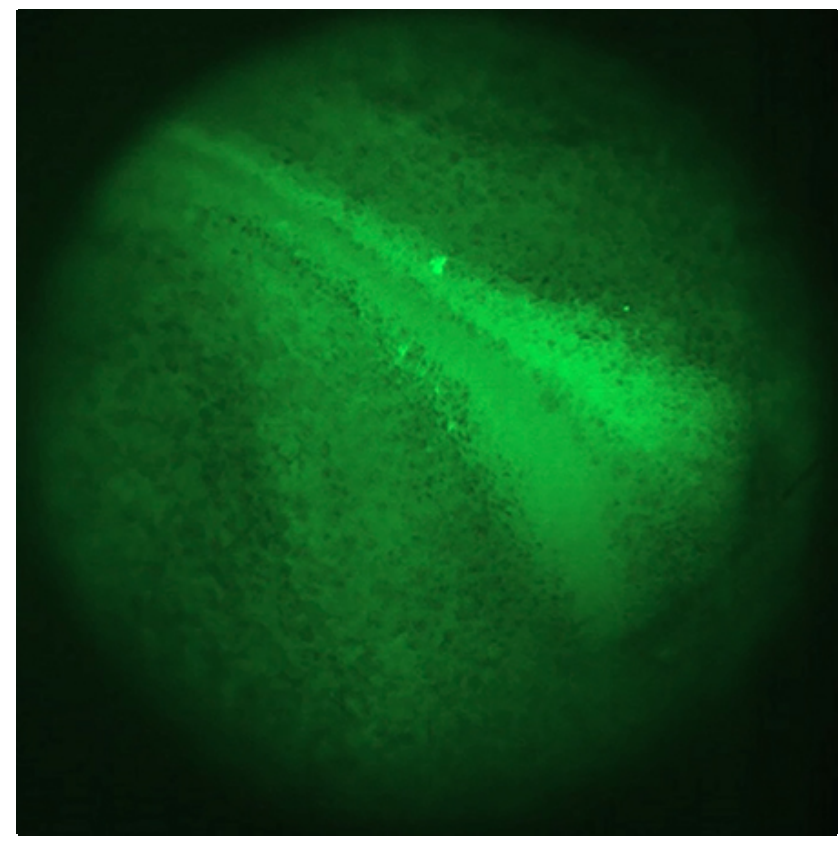

Movie 1. $\quad \mathrm{Ca}^{2+}$ transient frequency in the folding neural plate increases during neurulation. Stage 14 embryo expressing the $\mathrm{Ca}^{2+}$ sensor GCaMP6s was time-lapse imaged with an acquisition rate of $0.1 \mathrm{~Hz}$. Shown are the first and last $10 \mathrm{~min}$ from a $2 \mathrm{~h}$ recording. Speed is $50 \mathrm{X}$ real time.

and PCNA 1:4000 (catalog \#2586S, Cell Signaling Technology). Samples were then cleared with 1:2 benzyl alcohol/benzyl benzoate before imaging with a confocal microscope. The $z$-series for each whole mount was quantitatively analyzed with the image analysis software Imaris (Bitplane).

GluN1 knockdown. Two cell-stage embryos were bilaterally or unilaterally injected with $0.5-8 \mathrm{nl}$ of $1 \mathrm{~mm}$ GluN1-morpholinos (Mos) GluN1Mo1 and GluN1-Mo2 (Gene Tools), sequences written from 5' to 3' and complementary to $X$. laevis GluN1: AAAGGAAAAGGCGCATAGTGC CCAT and CTGTGCCAAGCGGAGCCAATGTCCT, respectively. Controls were sibling embryos injected with standard control-Mo (C-Mo; CCTCTTACCTCAGTTACAATTTATA, Gene Tools). Morpholinos were injected along with a tracer, dextran-Alexa-Fluor 568 or 647 (Thermo Fisher Scientific).

Rescue experiments of GluN1-Mo-injected embryos were implemented by coinjecting rat GluN1 mRNA, which is resistant to GluN1Mo, or by incubating embryos with $10 \mu \mathrm{M}$ NMDA starting at stages $2-4$ and continuing until after neurulation when embryos were fixed and processed for phenotype assessment. mRNA was synthesized as previously described (Swapna and Borodinsky, 2012; Belgacem and Borodinsky, 2015; Balashova et al., 2017) using the rat GluN1 template [pCI-EGFP-GluN1 wild type (WT); a gift from Andres Barria and Robert Malinow University of California San Diego, San Diego, California; plasmid \#45446, Addgene; Barria and Malinow, 2002]. Five hundred picograms of rGluN1 mRNA was bilaterally microinjected in two-cell-stage embryos ( $250 \mathrm{pg} /$ blastomere) with or without GluN1-Mo1.

Assessment of incidence and severity of neural tube defects. We determined the incidence of neural tube defects by examining whole stage 21 embryos and by evaluating the histology of the neural tube in transverse sections spanning the whole anteroposterior axis of stage 22-24 embryos. In whole embryos, the incidence of defective animals was recorded as the percentage of embryos exhibiting the neural tube defect phenotype consisting of the absence of neural fold convergence at the midline and protrusion, and detachment of the neural tissue. By examining, on average, 80 transverse sections of the neural tube along the whole extent of the anteroposterior axis, we recorded the incidence of embryos with neural tube defects as the percentage of embryos with any number of sections showing an open neural tube. The severity of the neural tube defect per embryo was determined as the proportion of the neural tube that remained open (percentage of sections with open neural tube with respect to the total number of sections collected along the entire anteroposterior axis per embryo). The sections were labeled with anti-E-cadherin antibody to distinguish between the covering up of the non-neural ectoderm versus the closure of the neural tube.

Measurements of neural plate cell divisions and oriented cell migration in live embryos. Two-cell-stage embryos were bilaterally injected with histone 2B-GFP mRNA (pCS-H2B-EGFP, a gift from Sean Megason, Harvard Medical School, Boston, MA; plasmid \#53744, Addgene; Megason, 2009) and unilaterally injected with 1 pmol GluN1-Mo or Control-Mo along with Alexa Fluor 568-conjugated dextran. Numbers of dividing cells were determined in time-lapse recordings of neurulating embryos over a $1.5 \mathrm{~h}$ period (stages 13-14) with an acquisition rate of one frame/3 min and normalized for the total number of H2B-GFP-expressing cells at each side of the neural plate. For oriented cell migration analysis, pairs of neural plate cells at comparable coordinates (distance from the midline and relative anteroposterior axis localization) were selected in wild-type and GluN1-Mo-containing tissue at the initial time frame, and their trajectories were tracked and measured during $2 \mathrm{~h}$ recordings (MTrackJ, Biomedical Imaging Group Rotterdam, Erasmus University Medical Center, Rotterdam, The Netherlands).

Pharmacological treatments. Neural plate stage embryos (starting at stage 13) were incubated with 5-500 $\mu \mathrm{M} \mathrm{D}$-AP5 (Tocris Bioscience), 0.1-1 mM VPA (Sigma-Aldrich and Tocris Bioscience), or vehicle only (saline). Rescue experiments for VPA-treated embryos were performed by preincubating them with $10 \mu \mathrm{M}$ NMDA starting at two- to four-cell stages or by preincubating embryos with cell proliferation inhibitors 20 mu hydroxyurea and $150 \mu \mathrm{m}$ aphidicolin (HUA; Sigma-Aldrich; Harris and Hartenstein, 1991) from stage 12.5 (30 min before VPA treatment). Additional rescue experiments for VPA- and D-AP5-treated embryos were performed by preincubating embryos expressing the inducible, constitutively active MEK1 (CA-MEK1-ER $\alpha$; injected at the two-cell stage with mRNA transcribed from subcloning of CA-MEK1-ER $\alpha$ from plasmid CC2, a gift from Paul Khavari, Stanford University, Stanford, California; plasmid \#21207, Addgene; Scholl et al., 2004) with $500 \mathrm{~nm}$ 4-hydroxy-tamoxifen (4-OHT) from stage 11. Incubation of wild-type embryos with 4-OHT from stage 11 did not affect the phenotype resulting from incubating embryos with vehicle, D-AP5, or VPA from stage 13 until stage 22.

A BrdU incorporation assay was performed by incubating stage 13 embryos with $4 \mathrm{mg} / \mathrm{ml} \mathrm{BrdU}$ (Sigma-Aldrich) for $5 \mathrm{~h}$.

Experimental design and statistical analysis. For in vivo experiments, at least 10 embryos were analyzed for each group, and experiments were repeated in at least three independent clutches. Significance was evaluated using Student's $t$ test or ANOVA followed by Tukey's or Dunnett's post hoc tests, and differences were considered significant at $p<0.05$. Categorical data were assessed using a $\chi^{2}$ test.

Embryos of both sexes were included in this study.

\section{Results}

\section{Calcium dynamics and glutamate signaling are present during neural tube formation}

Neural tube formation lasts $\sim 8 \mathrm{~h}$ in $X$. laevis embryos (Fig. $1 A$; Nieuwkoop and Faber (1994)). The expression of a genetically encoded $\mathrm{Ca}^{2+}$ sensor, GCaMP6s (Chen et al., 2013), reveals that ectodermal cells exhibit spontaneous $\mathrm{Ca}^{2+}$ transients (Fig. $1 B$, Movie 1). The frequency of transients increases with the progression of neural plate folding (Fig. $1 C$, Movie 1). These $\mathrm{Ca}^{2+}$ transients last for 30-80 s, and they are more frequent in central regions of the ectoderm, indicating that most of these transients occur in neuroepithelial cells (Fig. 1D, Movie 1).

Proteins involved in neurotransmission are expressed in the embryo before neuronal differentiation and synapse formation (Root et al., 2008). We detect transcripts for subunits of iono- 

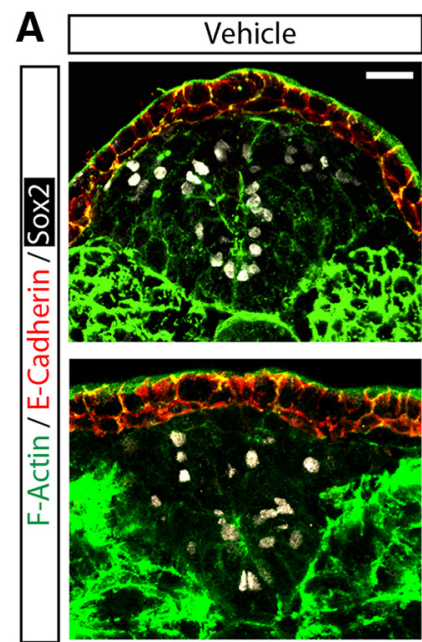

C

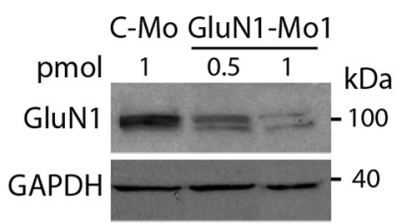

D
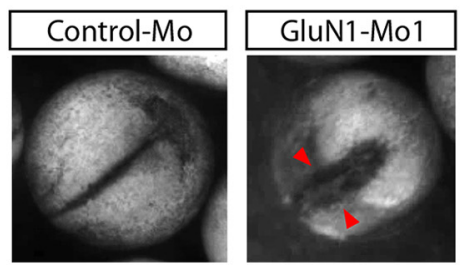

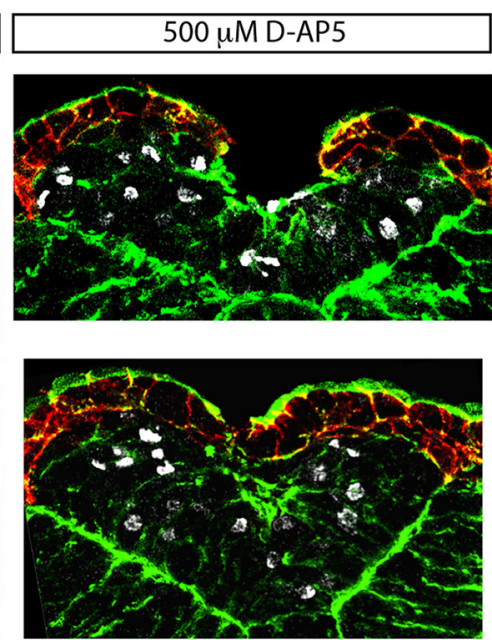

E

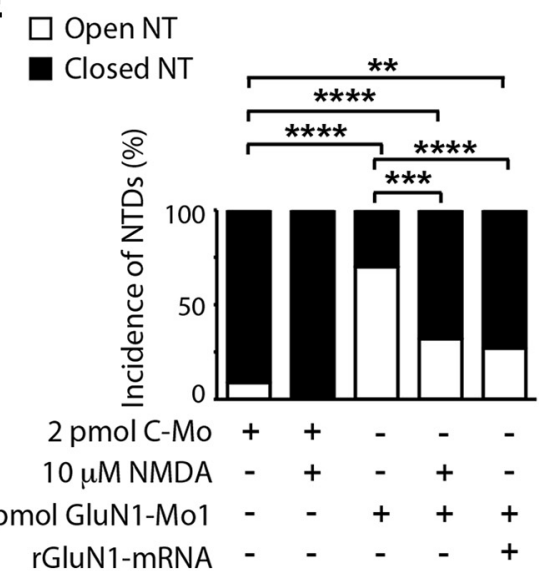

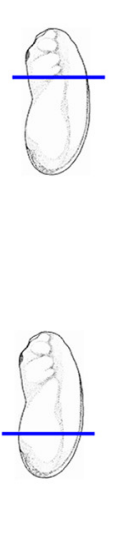

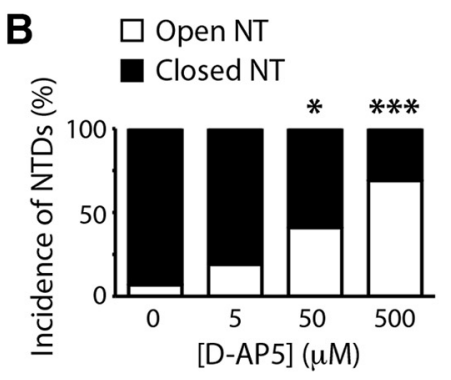

$\mathbf{F}$
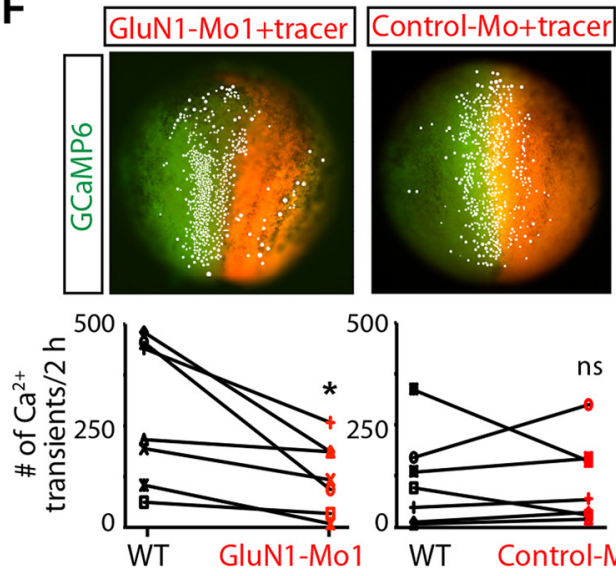

WT Control-Mo

Figure 2. NMDAR-mediated signaling is necessary for neural tube formation. $A, B$, Embryos were incubated with vehicle ( $0 \mu \mathrm{MD}$-AP5) or $5-500 \mu \mathrm{m} \mathrm{D}-\mathrm{AP} 5$ starting at stage 13 until stage 24 ( $\sim 11$ h incubation). $\boldsymbol{A}$, Immunostained transverse sections from stage 24 embryos incubated with vehicle or D-AP5. Scale bar, $20 \mu \mathrm{m}$. $\boldsymbol{B}$, Incidence of NTDs is the percentage of embryos with open neural tube (NT), $n \geq 15$ embryos per group. ${ }^{*} p<0.05,{ }^{* * *} p<0.001, \chi^{2}$ test compared with vehicle-incubated embryos. C, Western blot assays from whole, stage 18 embryos previously injected at the two-cell stage with GluN1-Mo1 or Control-morpholino (C-Mo). Similar results were obtained in three independent experiments. D, Examples of stage 21 embryos previously injected at the two-cell stage with control-Mo and GluN1-Mo1. Arrowheads indicate the failure of neural fold convergence in the midline. A comparable phenotype was obtained with GluN1-Mo2; hence, GluN1-Mo1 was used for the remainder of this study. E, Incidence of NTDs is the percentage of embryos with open neural tubes; values are the mean \pm SEM for $n>10$ embryos per group, $N \geq 5$ experiments. ${ }^{* *} p<$ $0.01,{ }^{* * *} p<0.001,{ }^{* * * *} p<0.0001, \chi^{2}$ test. $F$, Images illustrate embryos bilaterally expressing GCaMP6s and unilaterally containing GluN1-Mo1 or control-Mo and a fluorescent tracer. Circles indicate $\mathrm{Ca}^{2+}$ transients during a $2 \mathrm{~h}$ period (stages 12.5-14). Graphs show $\mathrm{Ca}^{2+}$ transient frequency (per $2 \mathrm{~h}$ period) in GluN1-Mo- or control-Mo-containing and contralateral (WT) neural plate in individual stage 12.5-14 embryos; $n=7$ GluN1-Mo and control-Mo embryos. ${ }^{*} p<0.05$, ns, not significant, paired $t$ test. Lines connect paired data from the same embryo.

tropic glutamate receptors GluN1 and GluA1, the VGluT1 and vesicular release machinery components: Stx1A, VAMP1, and SNAP25, in early neural plate stages (stage 13; Fig. 1E). In contrast, transcripts encoding EAAT5, expressed later in eye development, are not detected (Fig. $1 E$ ), serving as a negative control. GluN1 protein is also present during neural plate folding (stage 18; Fig. $1 F$ ). Western blot assays show that the same predicted molecular weight band is detected by the GluN1 antibody in neural plate and tailbud stages, the latter serving as a positive control for GluN1 expression during neurulation (Fig. $1 F$, top). In addition, the injection of either of two nonoverlapping $X$. laevis GluN1-targeted, translation-blocking Mos (GluN1-Mo) decreases GluN1 protein levels (Figs. 1F, 2C), proving specificity of the GluN1 antibody.

The addition of glutamate or NMDA induces acute $\mathrm{Ca}^{2+}$ transients in neural plate cells (Fig. $1 G$ ). Moreover, the incubation of neurulating embryos with D-AP5, a NMDAR antagonist, reduces the occurrence of spontaneous $\mathrm{Ca}^{2+}$ transients in the neural plate (Fig. $1 H, I$ ). These findings indicate that the neural plate exhibits glutamatergic signaling that results in $\mathrm{Ca}^{2+} \mathrm{dy}-$ namics mediated in part by NMDAR.

NMDA receptor signaling is necessary for neural tube closure To determine the role of NMDAR signaling in neural tube formation, we incubated embryos with D-AP5 starting at the early neural plate stages (stage 13; Fig. 1A). We determined the incidence of neural tube defects in D-AP5-treated embryos during neurulation by evaluating the histology of the neural tube in transverse sections of embryos at stage $24,4.5 \mathrm{~h}$ after neural tube closure had concluded in control individuals. Examining sections of the entire neural plate along the anteroposterior axis revealed that the neural tube remains open in D-AP5-treated embryos, although in some cases the non-neural ectoderm obscures the defective neural tube from external detection. The neural tissue looks flatter than in control embryos, and the neural folds fail to converge (Fig. $2 A, B$ ). Exposure of neurulating embryos to D-AP5 prevents the closure of the neural tube in a dose-dependent manner (Fig. $2 A, B$ ). The penetrance of NTDs due to D-AP5 
A

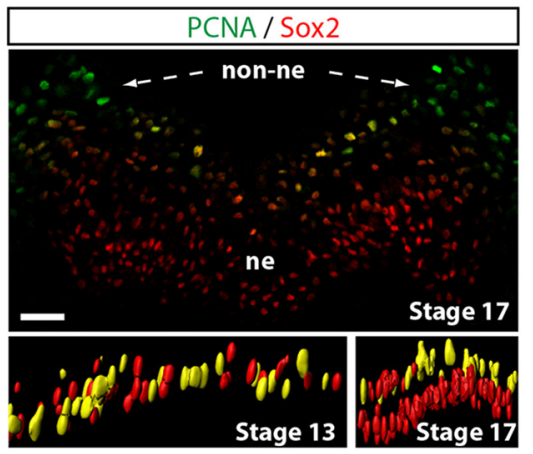

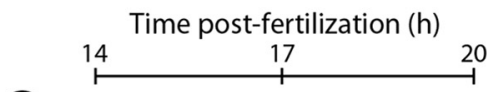

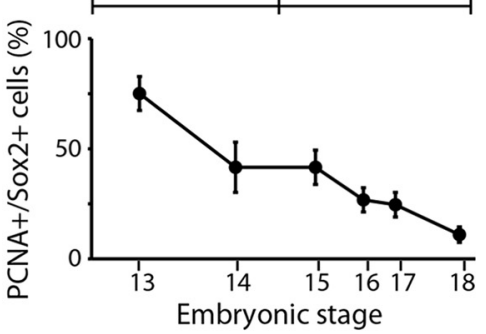

B
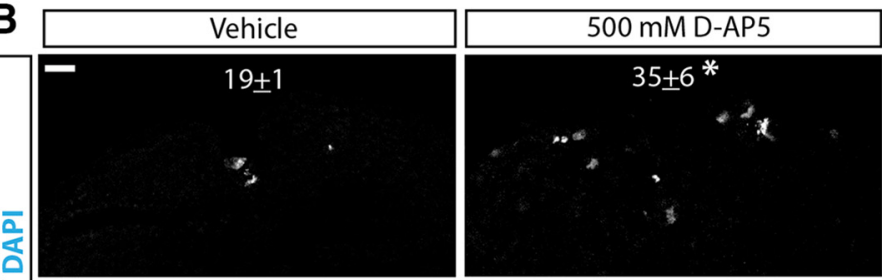

ำ

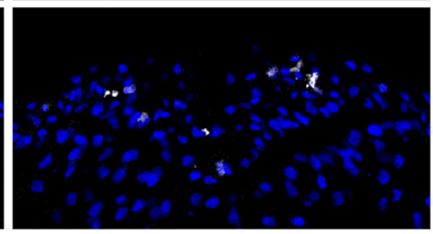

C
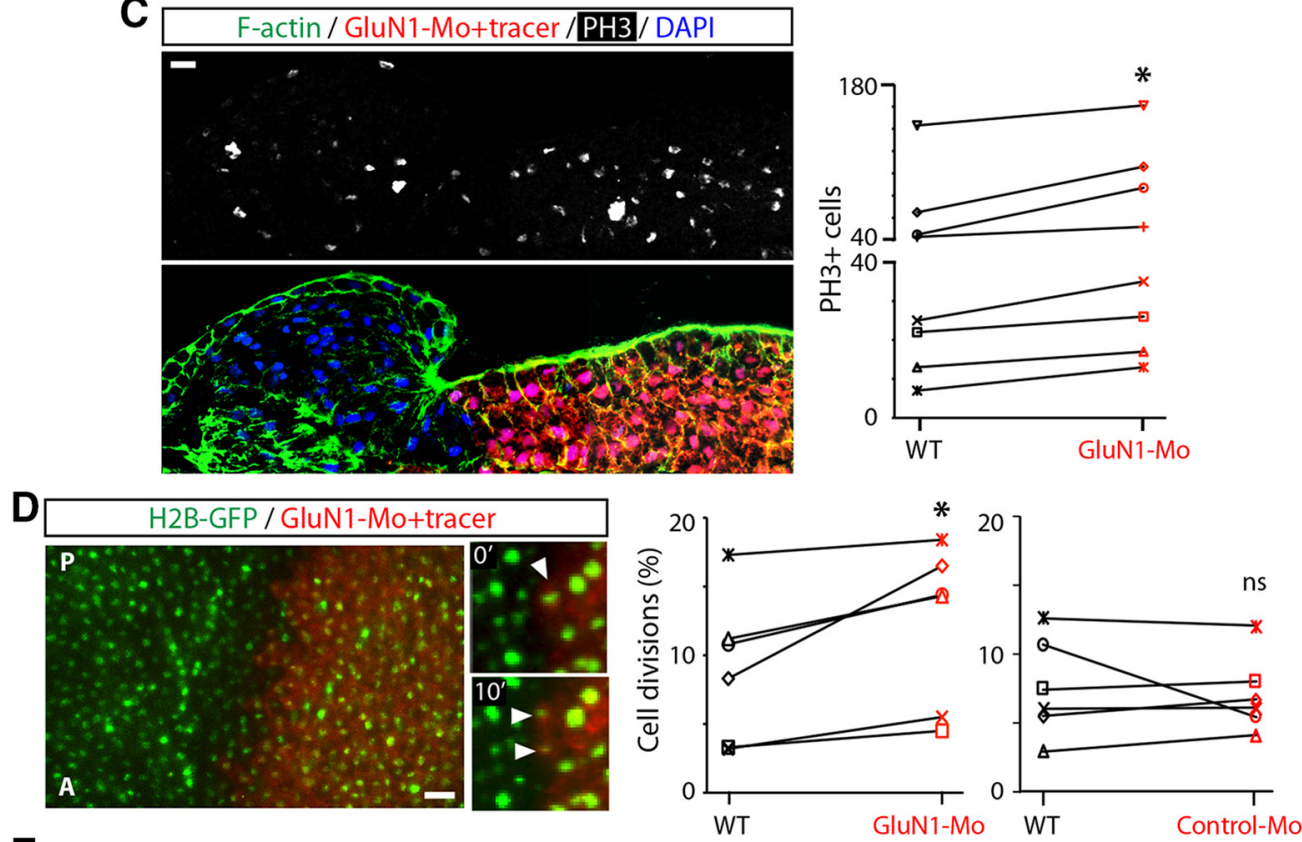

$\mathbf{E}$
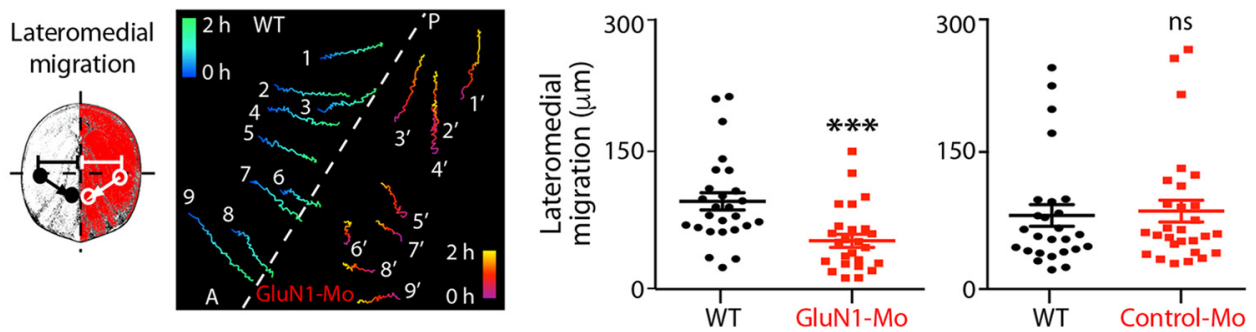

Figure 3. NMDA receptor signaling regulates neural plate cell proliferation and migration. $\boldsymbol{A}$, Whole-mount, immunostained stage 13 through stage 18 embryos were imaged coronally and analyzed using Imaris 3D software. Top image shows a single plane of a representative $z$-stack image of the dorsal half of a stage 17 embryo. Bottom images are volume renderings of virtual transverse sections of the neural plate in which Sox ${ }^{+}$cells were identified and analyzed for PCNA expression. ne, Neural ectoderm; non-ne, non-neural ectoderm. The graph shows the percentage of neural plate cells (identified by Sox2 expression) immunopositive for PCNA; values are the mean \pm SEM; $n=4-7$ embryos per stage. The line connects data points at sequential developmental stages (bottom, $x$-axis) corresponding to different times postfertilization (top, $x$-axis). $\boldsymbol{B}, \boldsymbol{C}$, Images illustrate immunostained transverse sections from vehicle and D-AP5-treated embryos (5 $\mathrm{h}$ incubation starting at stage $13 ; \boldsymbol{B}$ ) or from unilaterally GluN1-Mo-injected embryos during neural plate folding (stage $18 ; \boldsymbol{C}$. Numbers on the top of the images in $\boldsymbol{B}$ are (Figure legend continues.) 
incubation is not $100 \%$, even with D-AP5 concentrations known to saturate NMDAR. This may be due to the poor accessibility of D-AP5 (Morris, 1989) to neural plate cells located in deep layers of the folding neural plate leading to effective concentrations lower than the one in the bathing solution. Alternatively, the pharmacology and kinetic parameters of the embryonic NMDAR may differ from the mature receptor. The data show that NMDAR function is important for proper neural tube morphogenesis, which is in agreement with the teratogenic effects of NMDAR antagonists in chick embryos (Andaloro et al., 1998).

Knocking down the expression of the NMDAR subunit GluN1 by microinjecting either of two targeted translationblocking morpholinos (GluN1-Mo; Figs. 1F, 2C) induces NTDs (Fig. $2 D, E$ ). The presentation of the neural tube defect phenotype in whole embryos results in the absence of neural fold convergence at the midline, and protrusion and detachment of the neural tissue (Fig. 2D). The NTD phenotype is partially rescued by incubating embryos with $10 \mu \mathrm{M}$ NMDA or by restoring GluN1 expression (Fig. $2 E$ ), supporting the specificity of the GluN1 knockdown-induced NTD phenotype. Unilateral knockdown of GluN1 reveals that $\mathrm{Ca}^{2+}$ transient frequency in GluN1-deficient cells is significantly lower than that in wild type, contralateral neural plate cells (Fig. $2 F$ ), which is in agreement with an inhibition of $\mathrm{Ca}^{2+}$ transients in neural plate cells during folding by D-AP5 (Fig. $1 H, I$ ). In contrast, unilateral injection of a control-Mo does not affect $\mathrm{Ca}^{2+}$ transient frequency in the folding neural plate (Fig. $2 F$ ). These data demonstrate that glutamate signaling through NMDAR is necessary for a normal pattern of $\mathrm{Ca}^{2+}$ signaling during neurulation and for neural tube formation.

\section{NMDA receptor signaling regulates neural plate cell proliferation and oriented migration facilitating neural plate shaping during neurulation}

The cellular mechanisms necessary for neural tube formation include proliferation, polarization, and migration of neural and non-neural cells (Wallingford et al., 2013). In the X. laevis neural plate, data show that the number of proliferating cells immunolabeled for PCNA decreases with the advancement of neural plate

\footnotetext{
(Figure legend continued.) the number of $\mathrm{PH}^{+}{ }^{+}$cells in $1030-\mu \mathrm{m}$-thick sections of neural plate per embryo; values are the mean \pm SEM, $n=9$ embryos per group. ${ }^{*} p<0.05, t$ test. $C$, Graph shows the numbers of $\mathrm{PH}^{+}{ }^{+}$cells in 1030 - $\mu$ m-thick sections of WT and GluN1-Mocontaining halves of neural plate in individual embryos (stages $16-18$ ). ${ }^{*} p<0.05$, paired $t$ test. $\boldsymbol{D}, \boldsymbol{E}$, Embryos were unilaterally injected with GluN1-Mo or control-Mo, and bilaterally with H2B-GFP mRNA at the two-cell stage and time-lapse imaged starting at stage 13 for 1.5 (D) and $2(\boldsymbol{E})$ h. $\boldsymbol{D}$, Image on left shows a single frame from a time-lapse series (Movie 2) of an embryo bilaterally expressing H2B-GFP (green) and unilaterally containing GluN1-Mo + tracer (red). Magnified images to the right depict a cell division (arrowheads). Graphs show the number of cell divisions during $1.5 \mathrm{~h}$ starting at stage 13 in contralateral and ipsilateral halves of neural plate as the percentage of total H2B-GFP cells in each side; $n=6$ embryos per group. ${ }^{*} p<0.05$, $\mathrm{ns}$, not significant, paired $t$ test. Scale bars: $\boldsymbol{A}-\boldsymbol{D}, 20 \mu \mathrm{m}$. Lines in $\boldsymbol{C}$ and $\boldsymbol{D}$ connect paired data from the same embryo. $\boldsymbol{E}$, The trajectories of individual H2B-GFP-labeled cells were measured in both halves of the neural plate of embryos unilaterally containing GluN1-Mo or control-Mo during a $2 \mathrm{~h}$ period starting at stage 13 (Movie 2). Drawing on the left depicts the trajectories of individual cells (circles with straight arrows), and the lateromedial movement of these same cells (segments) that is reported in the graph. Schematic in the middle shows an example of the trajectories of pairs of cells initially equidistant from the midline (dashed line) in WT and GluN1-Mo-containing halves of neural plate over $2 \mathrm{~h}$ with numbers positioned at time 0 of the trajectory. Graphs show lateromedial displacement for individual WT and GluN1-Mo- or Control-Mo-containing cells and the mean $\pm \mathrm{SEM} ; n \geq 50$ cells, $N=3$ embryos per group. ${ }^{* * *} p<0.001, t$ test. P, Posterior; $A$, anterior.
}

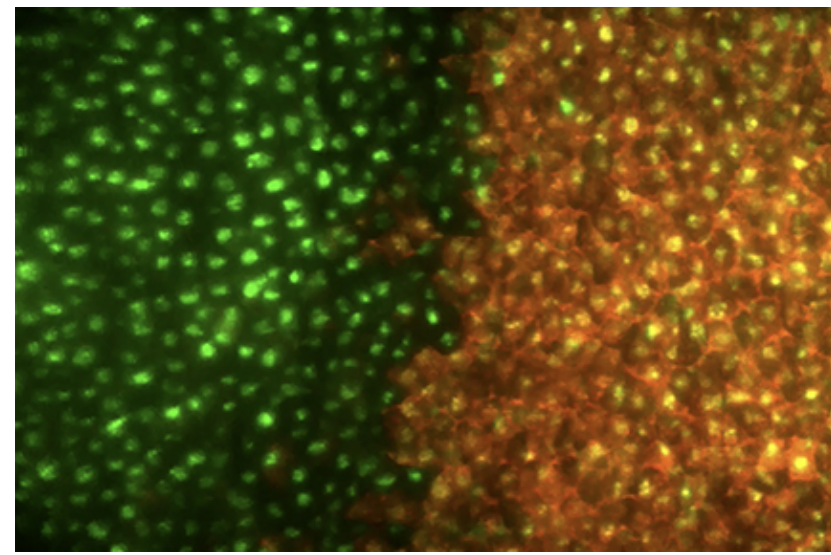

Movie 2. Time-lapse imaging of H2B-GFP-expressing neural plate stage embryos enables the detection of neural plate cell divisions and trajectories during neural tube formation. Two-cell stage embryos were unilaterally injected with $1 \mathrm{pmol}$ GluN1-Mo or Control-Mo (shown) and Alexa Fluor 568-conjugated dextran (red) and bilaterally injected with H2B-GFP (green). Movie shows a $2 \mathrm{~h}$ recording starting at stage 13 with an acquisition rate of $1 \mathrm{frame} / 3 \mathrm{~min}$.

folding during neurulation (Figs. $1 A, 3 A$ ). We find that inhibiting NMDAR by incubating early neural plate stage embryos with D-AP5 for $5 \mathrm{~h}$ increases the number of mitotic neural plate cells, immunolabeled for $\mathrm{PH} 3$, a mitotic marker [Fig. $3 B$ (average numbers of $\mathrm{PH}^{+}$cells are shown on top of representative images)]. Moreover, while the unilateral presence of control-Mo does not have a significant effect on the number of dividing cells during neurulation (Fig. 3D), knocking down GluN1 expression increases the number of mitotic neural plate cells (Fig. 3C) and neural plate cell divisions (Fig. 3D) compared with wild-type contralateral neural tissue, and the affected neural plate fails to fold (Fig. 3C).

Knockdown of GluN1 also perturbs the oriented displacement of neural plate cells during folding by reducing the lateromedial migration (Fig. 3E). In contrast, the presence of control-Mo does not change the pattern of neural plate cell movement (Fig. 3E).

These results indicate that glutamate signaling is necessary for modulating neural plate cell proliferation and for regulating oriented neural plate cell migration, both of which are required for proper neural tube formation.

\section{The antiepileptic drug valproic acid induces NTDs by inhibiting glutamate signaling}

We next sought to determine whether the AED VPA induces NTDs by affecting neurotransmitter signaling as it does in preventing epileptic seizures in the mature brain (Rogawski and Löscher, 2004). VPA induces NTDs in Xenopus embryos incubated with the drug during neurulation (Fig. $4 A, B$ ) as in other species including humans (Lindhout et al., 1992; Padmanabhan and Ahmed, 1996). The severity of the NTD, quantified by assessing the proportion of neural tube that remained open in each embryo, is concentration dependent (Fig. 4B). We used a VPA concentration range that is within the level found in pregnant women, fetuses and newborns (Nau et al., 1981, 1984; Kondo et al., 1987; Ardinger et al., 1988; Omtzigt et al., 1992; Vajda et al., 2013) and within the optimal range for VPA antiepileptic action (Eadie, 2001). We find that in some cases the non-neural ectoderm appears to converge normally at the midline over the defective neural tissue in VPA-treated embryos (Fig. 4A) in 

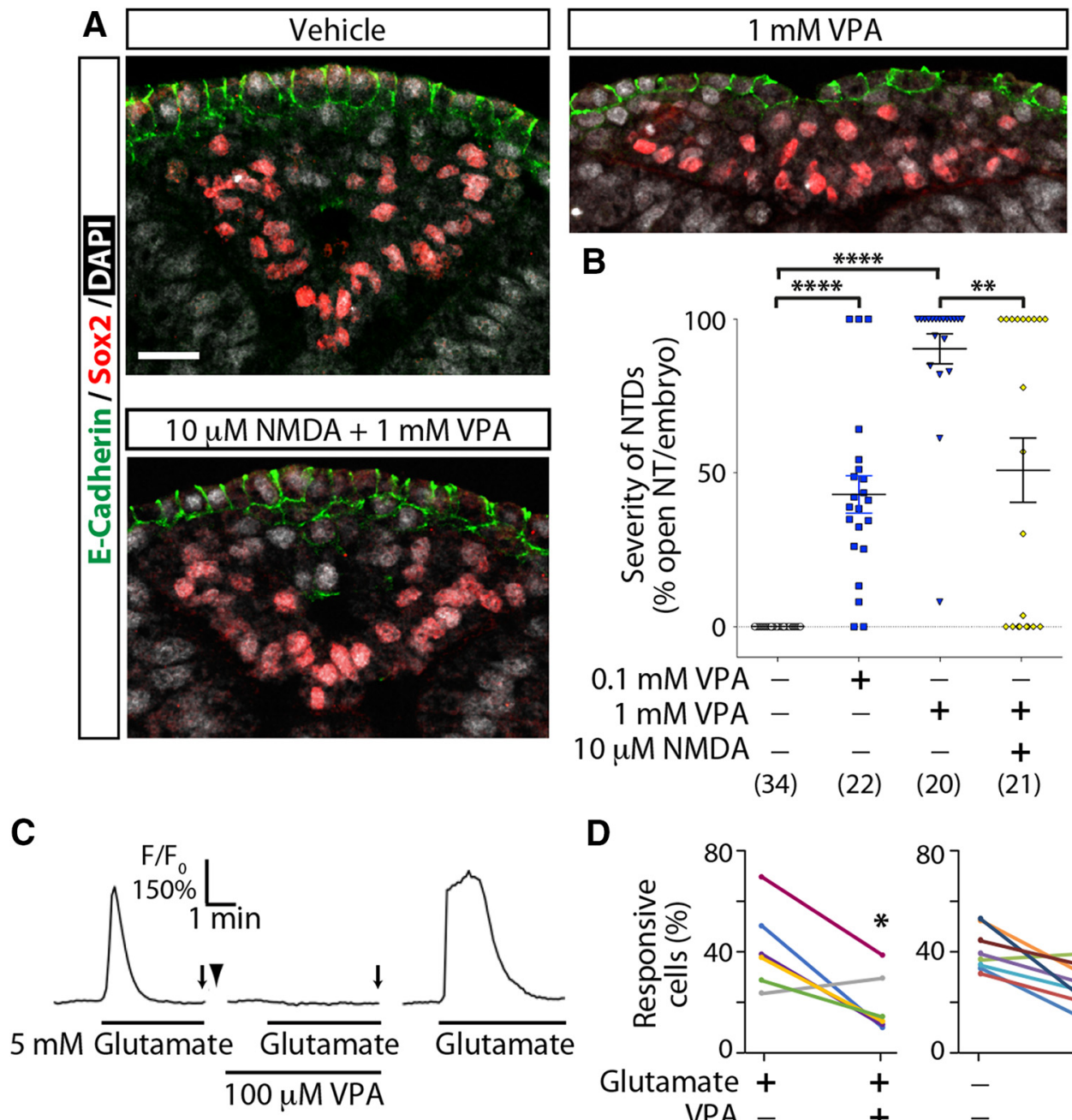

(34) (22) (20) (21)
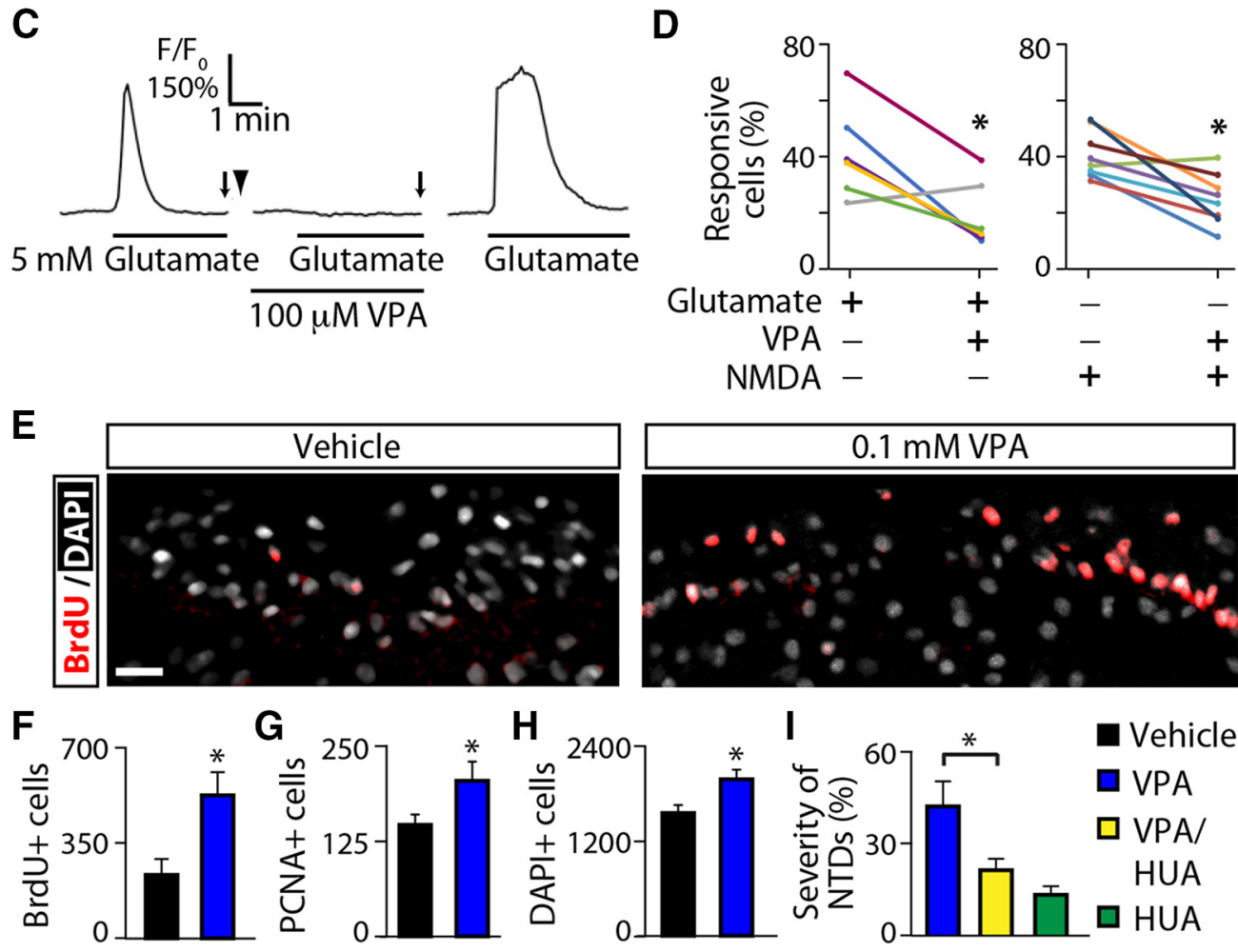

Figure 4. The antiepileptic drug VPA induces neural tube defects by interfering with glutamate signaling and by increasing neural plate cell proliferation. $A, B$, Embryos were incubated with vehicle (control) or $0.1-1 \mathrm{~mm}$ VPA starting at stage 13 or were preincubated with $10 \mu \mathrm{m} \mathrm{NMDA} \mathrm{starting} \mathrm{at} \mathrm{the} \mathrm{four-cell} \mathrm{stage} \mathrm{until} \mathrm{stages} 22-24$. $A$, Immunostained transverse sections from stage 22 vehicle-, VPA-, and VPA + NMDA-treated embryos. Sox 2 and E-cadherin immunostaining label neural and non-neural ectoderm, respectively. $\boldsymbol{B}$, Severity of NTDs is the percentage of transverse sections of the entire anteroposterior axis with open neural tube per embryo; values are the mean \pm SEM; between parentheses are the number of embryos per group, from at least three independent experiments. ${ }^{* *} p<0.005,{ }^{* * * *} p<0.0001$, ANOVA followed by Tukey's test. C, D, Dissociated neural plate cells from stage 15 embryos were loaded with the $\mathrm{Ca}^{2+}$-sensitive dye Fluo4-AM and imaged during the addition of $5 \mathrm{~mm}$ glutamate or $10 \mu \mathrm{M} \mathrm{NMDA}$ in the absence and presence (preincubation with VPA for $30 \mathrm{~min}$ ) of $100 \mu \mathrm{M}$ VPA. Cells were washed with saline for $10 \mathrm{~min}$ between recordings. Samples were time-lapse imaged at $0.2 \mathrm{~Hz}$. Regions of interest were selected to measure the fluorescence intensity over time for individual neural plate cells with NIS Elements software (Nikon). C, Shown is an example of a neural plate cell responsive to glutamate only in the absence of VPA. Lines under the traces indicate the time of incubation of the culture with glutamate or VPA. Arrows indicate the time when washes with saline were performed for 10 min. Arrowhead represents a 30 min preincubation with VPA. Fluorescence (F) is normalized to the baseline for each cell $\left(F_{0}\right)$ in percentage. $D$, Graphs show the numbers of cells responsive to 5 mm glutamate and $10 \mu \mathrm{m}$ NMDA as a percentage of the total number of cells in the field of view in the absence or presence of VPA for the same field of view; $n=6$ (glutamate, 70 cells recorded) and $n=8$ (NMDA, 217 cells recorded) independent experiments, ${ }^{*} p<0.05$, paired $t$ test. Lines connect paired data from the same field of view. $\boldsymbol{E}-\boldsymbol{H}$, Embryos were incubated starting at stage 13 with vehicle (control) or $0.1 \mathrm{~mm}$ VPA for $5 \mathrm{~h}$. In $\boldsymbol{E}$ and $\boldsymbol{F}$, BrdU was (Figure legend continues.) 
agreement with reports of skin-covered VPA-induced NTDs in humans (Clayton-Smith and Donnai, 1995).

VPA decreases the responsiveness of dissociated neural plate cells to glutamate and NMDA (Fig. $4 C, D$ ), which is in agreement with the inhibition of NMDAR-mediated synaptic transmission by VPA in adult rat amygdalar and neocortical slices (Zeise et al., 1991; Gean et al., 1994). VPA also inhibits the frequency of spontaneous $\mathrm{Ca}^{2+}$ transients in the neural plate in vivo (Fig. $1 \mathrm{H}, I$ ). Moreover, a partial rescue of VPA-induced NTDs is achieved when NMDAR signaling is enhanced (Fig. $4 A, B$ ), which is consistent with a partial restoration of the frequency of $\mathrm{Ca}^{2+}$ transients (Fig. 1H,I). The partial efficacy of the rescue of the VPA-induced NTD phenotype by preincubating embryos with NMDA could be due to better accessibility of VPA than of NMDA into deeper neural plate cells during neural tube formation. Indeed, we found that longer NMDA preincubation (starting at the four-cell stage) was more efficient in rescuing the NTD phenotype than was shorter NMDA preincubation (starting at stage 12.5; data not shown). Alternatively, the pattern of endogenous glutamate signaling, impaired by incubation with VPA, may not be accurately restored by chronic incubation with NMDA, resulting in a partial rescue of the NTD phenotype. Together, these data suggest that VPA acts on the neural plate by interfering with glutamate-mediated $\mathrm{Ca}^{2+}$ dynamics, resulting in defects in proliferation, oriented migration, and neural tube formation.

Supporting this idea, we find that VPA increases cell proliferation (Fig. $4 E-H$ ), replicating the effect of inhibiting NMDAR function (Fig. 3). Incubation of embryos with VPA during the first $5 \mathrm{~h}$ of neurulation results in an increase in the number of neural plate cells incorporating BrdU (Fig. 4E,F), more neural plate cells labeled with the proliferative marker PCNA (Fig. 4G), and a higher total number of cells in the affected neural plate (Fig. $4 H$ ). Moreover, blocking cell proliferation by inhibiting DNA synthesis through preincubation with HUA, partially rescues VPA-induced NTD phenotype by reducing the extent of open neural tube (Fig. 4I).

\section{ERK signaling is downstream NMDAR activation to facilitate neural tube closure}

In developing and mature neurons, NMDAR is known to activate ERK1/2 signaling through $\mathrm{Ca}^{2+}$ influx (Xia et al., 1996). Therefore, we investigated the involvement of ERK1/2 activation during glutamate signaling-dependent neural tube formation. First, we found that ERK1/2 activity increases during the progression of neural plate folding and falls again as this process concludes (Fig. $\left.5 A, A^{\prime}\right)$, in contrast to the profile of neural plate cell proliferation (Fig. 3A). Incubation of embryos with $10 \mu \mathrm{M}$ NMDA for $5 \mathrm{~min}$ during an early neural plate stage (stage 13), when ERK1/2 activity is low (Fig. $5 A$ ), is sufficient to activate ERK1/2 in neural plate cells (Fig. 5B). We then assessed whether activating ERK1/2 signaling (Fig. $5 C$ ) rescues the NTD phenotype induced by either the NMDAR antagonist D-AP5 or the AED VPA. Results show

\section{$\leftarrow$}

(Figure legend continued.) added to control and experimental groups during the $5 \mathrm{~h}$ of treatment. $\boldsymbol{E}$, Transverse sections immunolabeled for BrdU. Scale bars: $\boldsymbol{A}, \boldsymbol{E}, 20 \mu \mathrm{m}$. $\boldsymbol{F}-\boldsymbol{H}$, Graphs show the number of $\mathrm{BrdU}^{+}(\boldsymbol{F}), \mathrm{PCNA}^{+}(\boldsymbol{G})$, and $\mathrm{DAPI}^{+}(\boldsymbol{H})$ cells per $1030-\mu \mathrm{m}$-thick sections of neural plate per embryo; values are the mean $\pm \mathrm{SEM} ; n=9$ embryos per group. ${ }^{*} p<0.05$, $t$ test. $I$, Embryos were incubated with vehicle or $0.1 \mathrm{~mm}$ VPA starting at stage 13 and/or preincubated with HUA: $20 \mathrm{~mm}$ hydroxyurea $+150 \mu \mathrm{m}$ aphidicolin from stage 12.5 (30 min before VPA treatment) until stage 24. The severity of NTDs is the percentage of transverse sections of the entire anteroposterior axis with open neural tube per embryo, mean \pm SEM; $n \geq 10$ embryos per group. ${ }^{*} p<0.05$, ANOVA followed by Tukey's test. that the induction of an exogenously expressed, constitutively active MEK1 (Scholl et al., 2004), the activator of ERK1/2, completely rescues D-AP5- or VPA-induced NTDs (Fig. 5D). These results demonstrate that ERK1/2 is recruited by glutamate signaling, is sufficient for the NMDAR-dependent promotion of neural tube formation, and supports the model that VPA is interfering with neural tube formation through this pathway.

\section{Discussion}

This study demonstrates that glutamatergic signaling regulates neural plate cell proliferation and oriented cell migration, thus enabling appropriate neural tube formation. Disturbance of this signaling by AEDs leads to NTDs. Our findings agree with studies demonstrating the regulation of cell proliferation by neurotransmitter signaling in later embryonic stages, as well as in the postnatal and adult nervous system in rodents (Gould et al., 1994; LoTurco et al., 1995; Liu et al., 2005; Young et al., 2011). Precise regulation of neural plate cell proliferation is important for the success of neural tube formation as evidenced in two etiologically distinct models of spina bifida, the curly tail and Pax3 splotchdelayed mice, which exhibit increased cell proliferation in the open posterior neural tube (Keller-Peck and Mullen, 1997). In X. laevis, increased neural plate cell proliferation induced by overexpressing the transcription factor Tumorhead also results in failure of the neural folds to close and in excessive expansion of neural progenitor domains at the expense of neuronal differentiation (Wu et al., 2001). Notwithstanding, knockdown of Tumorhead in the Xenopus neural plate results in abnormal neural tube formation, presumably by decreasing neural plate cell proliferation, which leads to deficient neurogenesis (Wu et al., 2003). Similarly, in this study inhibiting DNA synthesis is also detrimental to neural tube formation. Altogether, these studies and our findings suggest that a tight regulation of neural plate cell proliferation is important for appropriate neural tube closure.

Our findings support a model in which glutamate signalingtriggered $\mathrm{Ca}^{2+}$ dynamics regulate neural plate cell proliferation and oriented migration during neural tube formation by recruiting ERK1/2 signaling. This recruitment may depend on the downstream participation of the $\mathrm{Ca}^{2+} /$ calmodulin-dependent kinase (Wei et al., 2006) or on direct interactions between NMDAR subunits and $\mathrm{Ca}^{2+} /$ calmodulin-dependent Ras-guaninenucleotide-releasing factor (Krapivinsky et al., 2003). Despite the known function of ERK1/2 activation in cell proliferation, the recruitment of ERK1/2 upon glutamate signaling is known to lead to nonproliferative actions, such as neuronal differentiation, through the regulation of expression of immediate early genes (Xia et al., 1996) and long-lasting long-term potentiation (Zhai et al., 2013). The duration of ERK1/2 activation, regulated by feedback mechanisms triggered by $\mathrm{Ca}^{2+}$ dynamics (Paul et al., 2003), is crucial to the cellular outcome (Marshall, 1995; Scott and Pawson, 2009). In particular, $\mathrm{Ca}^{2+}$ transients in Xenopus neuroectodermal cells are known to regulate apical constriction in the folding neural plate by inducing actin contraction pulses, process important for neural tube closure (Christodoulou and Skourides, 2015). It has also been shown that $\mathrm{T}$-type $\mathrm{Ca}^{2+}$ channels expressed in the anterior neural folds are necessary for their fusion and closure of the neural tube in X. laevis and in the primitive chordate Ciona savignyi (Abdul-Wajid et al., 2015). We find that the increase in the number of proliferative cells when glutamate signaling is inhibited is accompanied by impaired oriented migration of neural plate cells. This suggests that the persistence of proliferative status of the cell may interfere with the cytoskeletal dynamics necessary for the folding of the neural plate and the 

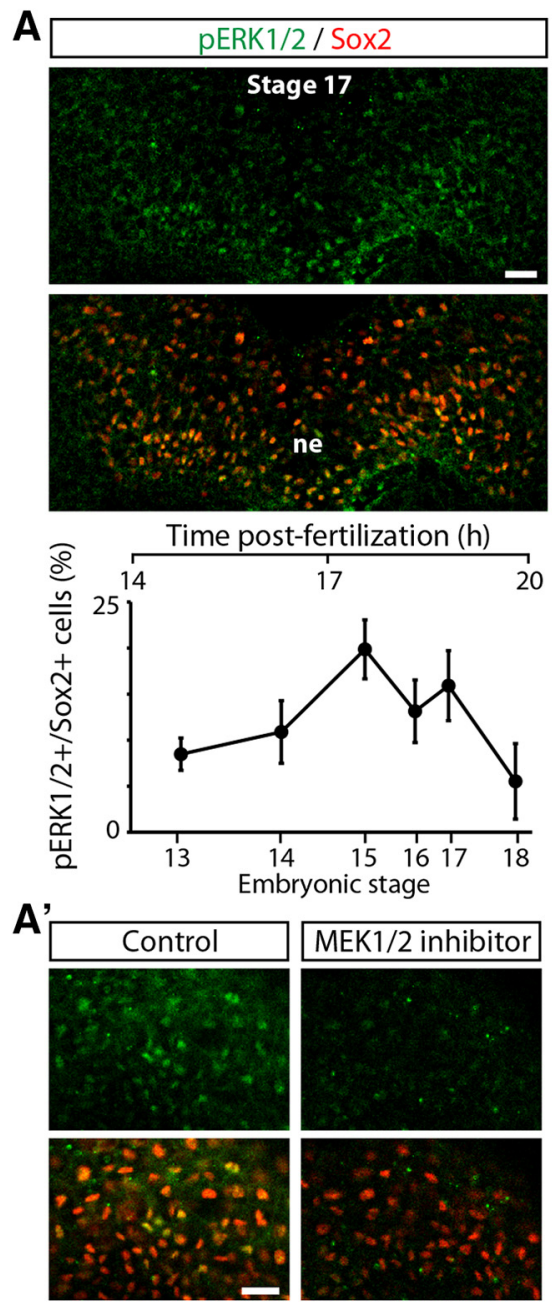

B

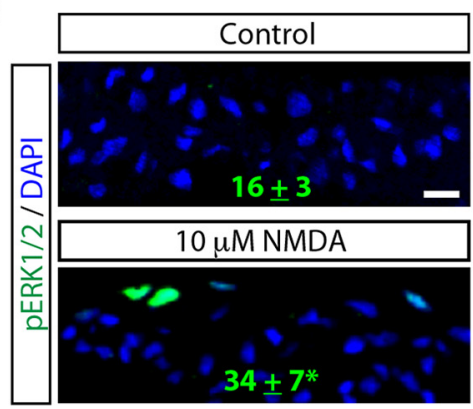

C

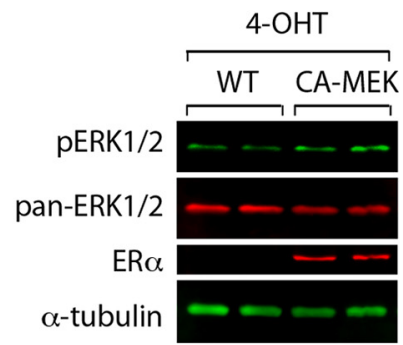

D
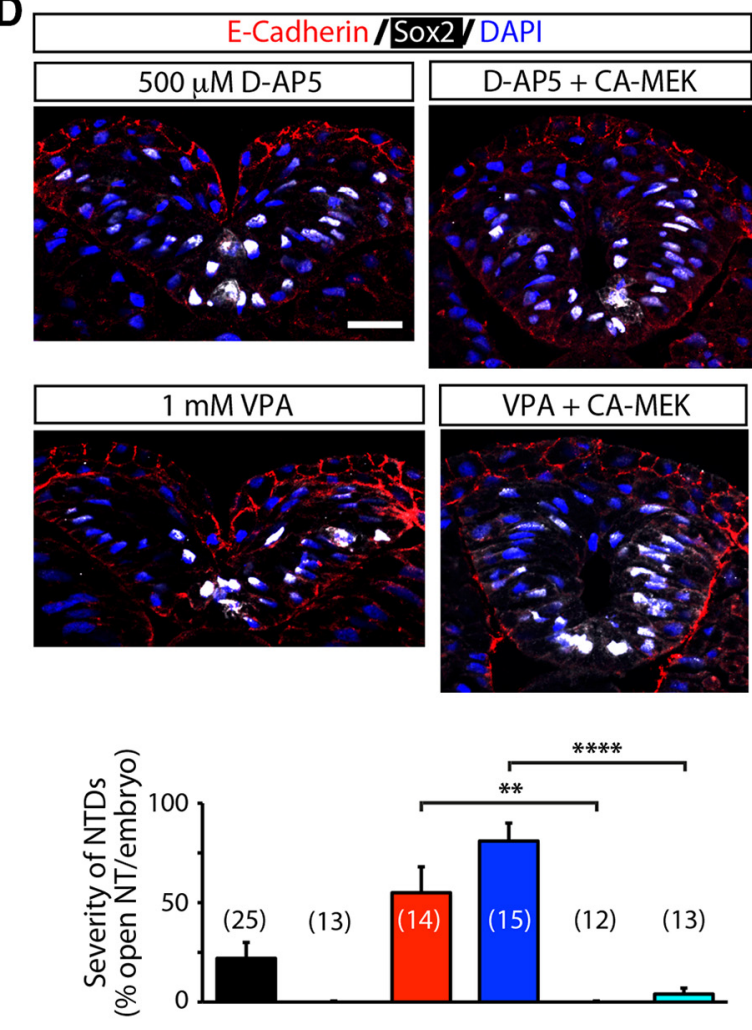

$500 \mathrm{nM} 4-\mathrm{OHT}+\quad+\quad+\quad+\quad+\quad+$

CA-MEK $\quad-\quad+\quad-\quad-\quad+\quad+\quad+$

$500 \mu \mathrm{MD}-\mathrm{AP5} \quad-\quad-\quad+\quad+\quad-\quad+\quad+$

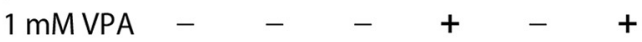

Figure 5. ERK1/2 activation is downstream of glutamate-NMDAR signaling in the promotion of neural tube closure. $A$, Whole-mount stage 13 through stage 18 embryos immunostained for pERK1/2 and Sox 2 were imaged coronally and analyzed using Imaris 3D software. Images show a single plane of a representative $z$-stack of the dorsal half of a stage $17 \mathrm{embry}$. ne, Neural ectoderm. The graph shows the percentage of pERK1/2-immunopositive neural plate cells identified by Sox2 expression; values are the mean \pm SEM, $n=4-7$ embryos per stage. The line connects data points at sequential developmental stages (bottom $x$-axis) corresponding to different times postfertilization (top $x$-axis). $\boldsymbol{A}^{\prime}$, To confirm specificity of the pERK1/2 antibody, embryos were incubated with either vehicle (control) or $10 \mu \mathrm{M}$ PD0325901 (MEK1/2 inhibitor) from stage 11.5 to stage 15, then were processed for whole-mount immmunostaining. $\boldsymbol{B}$, Stage 13 embryos were incubated with 10 $\mu \mathrm{M}$ NMDA or vehicle (control) for 5 min followed by processing for pERK1/2 immunostaining. Shown are immunostained transverse sections of neural plate and number of pERK $1 / 2$-immunopositive cells per $1030 \mu \mathrm{m}$ sections of neural plate per embryo; values are the mean $\pm \mathrm{SEM} ; n=14$ embryos per treatment. ${ }^{* *} p<0.005, t$ test. C, Western blot assay from whole-embryo lysates of WT and CA-MEK1-ER $\alpha$ expressing (CA-MEK) stage 15 embryos treated with $500 \mathrm{~nm}$ 4-0HT from stage 11. Similar results were obtained in three independent experiments. D, Activation of ERK1/2 rescues D-AP5 or VPA-induced NTD. WT or CA-MEK-injected embryos were incubated with 4-OHT from stage 11 followed by incubation with vehicle or with $500 \mu \mathrm{M} \mathrm{D-AP5}$ or $1 \mathrm{~mm}$ VPA from stage 13 , then fixed and processed for transverse sectioning and immunostaining at stage 22, as shown in images. Graph shows the severity of NTDs, which is the percentage of transverse sections of the entire anteroposterior axis with open neural tube per embryo; values are the mean \pm SEM; between parentheses are the number of embryos per group, from at least three independent experiments. ${ }^{* * * *} p<0.0001$, one-way ANOVA followed by Tukey's test. Scale bars, $20 \mu \mathrm{m}$.

formation of the neural tube and that $\mathrm{Ca}^{2+}$ dynamics are needed to enable this transition.

We find that VPA mimics the NMDAR inhibitor in that it inhibits $\mathrm{Ca}^{2+}$ dynamics in neural plate cells during neural plate folding, resulting in an increase in neural plate cell proliferation. Moreover, NMDA partially rescues the VPA-induced NTD phenotype. These findings suggest that VPA perturbs neural tube formation by targeting NMDAR-mediated glutamate signaling. 
VPA-induced increase in cell proliferation is also seen in rat neuronal progenitors grown in vitro by a mechanism independent of histone deacetylase (HDAC) inhibition, a known off-target effect of VPA (Laeng et al., 2004). Indeed, the inhibition of HDACs by VPA would be expected to decrease cell proliferation, since HDACs lead to more compacted chromatin enabling proliferation and inhibiting cell differentiation (Lane and Chabner, 2009). Altogether, the results suggest that the primary neural activityrelated targets of VPA are likely responsible for the increase in neural plate cell proliferation and consequently for the occurrence of NTDs.

This study suggests that the identification of AEDs that do not target NMDAR signaling or the development of strategies that counteract this effect in the neural plate may reduce the incidence of neural tube defects in offspring of epileptic patients.

\section{References}

Abdul-Wajid S, Morales-Diaz H, Khairallah SM, Smith WC (2015) T-type calcium channel regulation of neural tube closure and EphrinA/EPHA expression. Cell Rep 13:829-839. CrossRef Medline

Andaloro VJ, Monaghan DT, Rosenquist TH (1998) Dextromethorphan and other $\mathrm{N}$-methyl-D-aspartate receptor antagonists are teratogenic in the avian embryo model. Pediatr Res 43:1-7. CrossRef Medline

Ardinger HH, Atkin JF, Blackston RD, Elsas LJ, Clarren SK, Livingstone S, Flannery DB, Pellock JM, Harrod MJ, Lammer EJ (1988) Verification of the fetal valproate syndrome phenotype. Am J Med Genet 29:171-185. CrossRef Medline

Balashova OA, Visina O, Borodinsky LN (2017) Folate receptor 1 is necessary for neural plate cell apical constriction during Xenopus neural tube formation. Development 144:1518-1530. CrossRef Medline

Barria A, Malinow R (2002) Subunit-specific NMDA receptor trafficking to synapses. Neuron 35:345-353. CrossRef Medline

Belgacem YH, Borodinsky LN (2011) Sonic hedgehog signaling is decoded by calcium spike activity in the developing spinal cord. Proc Natl Acad Sci U S A 108:4482-4487. CrossRef Medline

Belgacem YH, Borodinsky LN (2015) Inversion of sonic hedgehog action on its canonical pathway by electrical activity. Proc Natl Acad Sci U S A 112:4140-4145. CrossRef Medline

Borodinsky LN, Spitzer NC (2007) Activity-dependent neurotransmitterreceptor matching at the neuromuscular junction. Proc Natl Acad Sci U S A 104:335-340. CrossRef Medline

Borodinsky LN, Root CM, Cronin JA, Sann SB, Gu X, Spitzer NC (2004) Activity-dependent homeostatic specification of transmitter expression in embryonic neurons. Nature 429:523-530. CrossRef Medline

Bortone D, Polleux F (2009) KCC2 expression promotes the termination of cortical interneuron migration in a voltage-sensitive calcium-dependent manner. Neuron 62:53-71. CrossRef Medline

Chen TW, Wardill TJ, Sun Y, Pulver SR, Renninger SL, Baohan A, Schreiter ER, Kerr RA, Orger MB, Jayaraman V, Looger LL, Svoboda K, Kim DS (2013) Ultrasensitive fluorescent proteins for imaging neuronal activity. Nature 499:295-300. CrossRef Medline

Christodoulou N, Skourides PA (2015) Cell-autonomous $\mathrm{Ca}(2+)$ flashes elicit pulsed contractions of an apical actin network to drive apical constriction during neural tube closure. Cell Rep 13:2189-2202. CrossRef Medline

Clayton-Smith J, Donnai D (1995) Fetal valproate syndrome. J Med Genet 32:724-727. CrossRef Medline

Eadie MJ (2001) Therapeutic drug monitoring—antiepileptic drugs. Br J Clin Pharmacol 52 [Suppl 1]:11S-20S. Medline

Finnell RH, Gould A, Spiegelstein O (2003) Pathobiology and genetics of neural tube defects. Epilepsia 44 [Suppl 3]:14-23. CrossRef Medline

Gean PW, Huang CC, Hung CR, Tsai JJ (1994) Valproic acid suppresses the synaptic response mediated by the NMDA receptors in rat amygdalar slices. Brain Res Bull 33:333-336. CrossRef Medline

Gould E, Cameron HA, McEwen BS (1994) Blockade of NMDA receptors increases cell death and birth in the developing rat dentate gyrus. J Comp Neurol 340:551-565. CrossRef Medline

Gurvich N, Berman MG, Wittner BS, Gentleman RC, Klein PS, Green JB (2005) Association of valproate-induced teratogenesis with histone deacetylase inhibition in vivo. FASEB J 19:1166-1168. CrossRef Medline
Harris WA, Hartenstein V (1991) Neuronal determination without cell division in xenopus embryos. Neuron 6:499-515. CrossRef Medline

Kapur RP, Hoyle GW, Mercer EH, Brinster RL, Palmiter RD (1991) Some neuronal cell populations express human dopamine beta-hydroxylaselacZ transgenes transiently during embryonic development. Neuron 7:717-727. CrossRef Medline

Keller-Peck CR, Mullen RJ (1997) Altered cell proliferation in the spinal cord of mouse neural tube mutants curly tail and Pax3 splotch-delayed. Brain Res Dev Brain Res 102:177-188. CrossRef Medline

Kondo T, Otani K, Hirano T, Kaneko S (1987) Placental transfer and neonatal elimination of mono-unsaturated metabolites of valproic acid. Br J Clin Pharmacol 24:401-403. CrossRef Medline

Krapivinsky G, Krapivinsky L, Manasian Y, Ivanov A, Tyzio R, Pellegrino C, Ben-Ari Y, Clapham DE, Medina I (2003) The NMDA receptor is coupled to the ERK pathway by a direct interaction between NR2B and RasGRF1. Neuron 40:775-784. CrossRef Medline

Laeng P, Pitts RL, Lemire AL, Drabik CE, Weiner A, Tang H, Thyagarajan R, Mallon BS, Altar CA (2004) The mood stabilizer valproic acid stimulates GABA neurogenesis from rat forebrain stem cells. J Neurochem 91:238 251. CrossRef Medline

Lane AA, Chabner BA (2009) Histone deacetylase inhibitors in cancer therapy. J Clin Oncol 27:5459-5468. CrossRef Medline

Lauder JM, Wallace JA, Krebs H (1981) Roles for serotonin in neuroembryogenesis. Adv Exp Med Biol 133:477-506. CrossRef Medline

Lindhout D, Schmidt D (1986) In-utero exposure to valproate and neural tube defects. Lancet 1:1392-1393. Medline

Lindhout D, Omtzigt JG, Cornel MC (1992) Spectrum of neural-tube defects in 34 infants prenatally exposed to antiepileptic drugs. Neurology 42:111-118. CrossRef Medline

Liu X, Wang Q, Haydar TF, Bordey A (2005) Nonsynaptic GABA signaling in postnatal subventricular zone controls proliferation of GFAPexpressing progenitors. Nat Neurosci 8:1179-1187. CrossRef Medline

LoTurco JJ, Owens DF, Heath MJ, Davis MB, Kriegstein AR (1995) GABA and glutamate depolarize cortical progenitor cells and inhibit DNA synthesis. Neuron 15:1287-1298. CrossRef Medline

Luk KC, Kennedy TE, Sadikot AF (2003) Glutamate promotes proliferation of striatal neuronal progenitors by an NMDA receptor-mediated mechanism. J Neurosci 23:2239-2250. CrossRef Medline

Manent JB, Demarque M, Jorquera I, Pellegrino C, Ben-Ari Y, Aniksztejn L, Represa A (2005) A noncanonical release of GABA and glutamate modulates neuronal migration. J Neurosci 25:4755-4765. CrossRef Medline

Manent JB, Jorquera I, Ben-Ari Y, Aniksztejn L, Represa A (2006) Glutamate acting on AMPA but not NMDA receptors modulates the migration of hippocampal interneurons. J Neurosci 26:5901-5909. CrossRef Medline

Marshall CJ (1995) Specificity of receptor tyrosine kinase signaling: transient versus sustained extracellular signal-regulated kinase activation. Cell 80:179-185. CrossRef Medline

Megason SG (2009) In toto imaging of embryogenesis with confocal timelapse microscopy. Methods Mol Biol 546:317-332. CrossRef Medline

Morris RG (1989) Synaptic plasticity and learning: selective impairment of learning rats and blockade of long-term potentiation in vivo by the $N$-methyl-D-aspartate receptor antagonist AP5. J Neurosci 9:3040-3057. CrossRef Medline

Namimatsu S, Ghazizadeh M, Sugisaki Y (2005) Reversing the effects of formalin fixation with citraconic anhydride and heat: a universal antigen retrieval method. J Histochem Cytochem 53:3-11. CrossRef Medline

Nau H, Rating D, Koch S, Häuser I, Helge H (1981) Valproic acid and its metabolites: placental transfer, neonatal pharmacokinetics, transfer via mother's milk and clinical status in neonates of epileptic mothers. J Pharmacol Exp Ther 219:768-777. Medline

Nau H, Helge H, Luck W (1984) Valproic acid in the perinatal period: decreased maternal serum protein binding results in fetal accumulation and neonatal displacement of the drug and some metabolites. J Pediatr 104: 627-634. CrossRef Medline

Nieuwkoop PD, Faber J (1994) Normal table of Xenopus laevis (Daudin): a systematical and chronological survey of the development from the fertilized egg till the end of metamorphosis. New York: Garland.

Omtzigt JG, Nau H, Los FJ, Pijpers L, Lindhout D (1992) The disposition of valproate and its metabolites in the late first trimester and early second trimester of pregnancy in maternal serum, urine, and amniotic fluid: 
effect of dose, co-medication, and the presence of spina bifida. Eur J Clin Pharmacol 43:381-388. CrossRef Medline

Padmanabhan R, Ahmed I (1996) Sodium valproate augments spontaneous neural tube defects and axial skeletal malformations in $\mathrm{TO}$ mouse fetuses [corrected]. Reprod Toxicol 10:345-363. CrossRef Medline

Paul S, Nairn AC, Wang P, Lombroso PJ (2003) NMDA-mediated activation of the tyrosine phosphatase STEP regulates the duration of ERK signaling. Nat Neurosci 6:34-42. CrossRef Medline

Robert E, Guibaud P (1982) Maternal valproic acid and congenital neural tube defects. Lancet 2:937. Medline

Rogawski MA, Löscher W (2004) The neurobiology of antiepileptic drugs for the treatment of nonepileptic conditions. Nat Med 10:685-692. CrossRef Medline

Root CM, Velázquez-Ulloa NA, Monsalve GC, Minakova E, Spitzer NC (2008) Embryonically expressed GABA and glutamate drive electrical activity regulating neurotransmitter specification. J Neurosci 28:47774784. CrossRef Medline

Rosa FW (1991) Spina bifida in infants of women treated with carbamazepine during pregnancy. N Engl J Med 324:674-677. CrossRef Medline

Rowe SJ, Messenger NJ, Warner AE (1993) The role of noradrenaline in the differentiation of amphibian embryonic neurons. Development 119: 1343-1357. Medline

Scholl FA, Dumesic PA, Khavari PA (2004) Mek1 alters epidermal growth and differentiation. Cancer Res 64:6035-6040. CrossRef Medline

Scott JD, Pawson T (2009) Cell signaling in space and time: where proteins come together and when they're apart. Science 326:1220-1224. CrossRef Medline

Spitzer NC (2006) Electrical activity in early neuronal development. Nature 444:707-712. CrossRef Medline

Swapna I, Borodinsky LN (2012) Interplay between electrical activity and bone morphogenetic protein signaling regulates spinal neuron differentiation. Proc Natl Acad Sci U S A 109:16336-16341. CrossRef Medline

Tu MK, Borodinsky LN (2014) Spontaneous calcium transients manifest in the regenerating muscle and are necessary for skeletal muscle replenishment. Cell Calcium 56:34-41. CrossRef Medline
Vajda FJ, O’Brien TJ, Graham JE, Lander CM, Eadie MJ (2013) Dose dependence of fetal malformations associated with valproate. Neurology 81: 999-1003. CrossRef Medline

Wallingford JB, Niswander LA, Shaw GM, Finnell RH (2013) The continuing challenge of understanding, preventing, and treating neural tube defects. Science 339:1222002. CrossRef Medline

Wegner C, Nau H (1992) Alteration of embryonic folate metabolism by valproic acid during organogenesis: implications for mechanism of teratogenesis. Neurology 42:17-24. Medline

Wei F, Vadakkan KI, Toyoda H, Wu LJ, Zhao MG, Xu H, Shum FW, Jia YH, Zhuo M (2006) Calcium calmodulin-stimulated adenylyl cyclases contribute to activation of extracellular signal-regulated kinase in spinal dorsal horn neurons in adult rats and mice. J Neurosci 26:851-861. CrossRef Medline

Wu CF, Nakamura H, Chan AP, Zhou YH, Cao T, Kuang J, Gong SG, He G, Etkin LD (2001) Tumorhead, a xenopus gene product that inhibits neural differentiation through regulation of proliferation. Development 128: 3381-3393. Medline

Wu CF, Chan AP, Etkin LD (2003) Difference in the maternal and zygotic contributions of tumorhead on embryogenesis. Dev Biol 255:290-302. CrossRef Medline

Xia Z, Dudek H, Miranti CK, Greenberg ME (1996) Calcium influx via the NMDA receptor induces immediate early gene transcription by a MAP kinase/ERK-dependent mechanism. J Neurosci 16:5425-5436. CrossRef Medline

Young SZ, Taylor MM, Bordey A (2011) Neurotransmitters couple brain activity to subventricular zone neurogenesis. Eur J Neurosci 33:11231132. CrossRef Medline

Zeise ML, Kasparow S, Zieglgänsberger W (1991) Valproate suppresses $\mathrm{N}$-methyl-D-aspartate-evoked, transient depolarizations in the rat neocortex in vitro. Brain Res 544:345-348. CrossRef Medline

Zhai S, Ark ED, Parra-Bueno P, Yasuda R (2013) Long-distance integration of nuclear ERK signaling triggered by activation of a few dendritic spines. Science 342:1107-1111. CrossRef Medline 